\title{
The Utility of Visceral Adiposity Index in Prediction of Metabolic Syndrome and Hypercholesterolemia
}

\author{
BOGDAN SOCEA ${ }^{1 \#, ~ L U C R E T I U ~ R A D U 2 \#, ~ D I A N A ~ C L E N C I U 3 \#, ~ T I B E R I U ~ S T E F A N I T A ~ T E N E A ~ C O J A N *, ~ V L A D ~ B A L E A N U 5, ~}$ \\ CRISTINA GABRIELA ENE ${ }^{6}$, SIGINA RODICA GIRGAVU', IONELA MIHAELA VLADU ${ }^{8}$ \\ ${ }^{1}$ General Surgery Clinic, Emergency Clinical Hospital Sfantul Pantelimon, Bucharest, Romania, 340-342 Soseaua Pantelimon, \\ 021659, Bucharest, Romania \\ 2University of Medicine and Pharmacy of Craiova, Department of Hygiene, CFR Hospital of Craiova, Stirbei-Voda Str., 200374, \\ Craiova, Romania \\ ${ }^{3}$ Filantropia Clinical Hospital of Craiova, 1 Filantropiei Str., 200143, Craiova, Romania \\ ${ }^{4}$ University of Medicine and Pharmacy of Craiova, Department of Surgery, CFR Hospital of Craiova, Stirbei-Voda Str., 200374, \\ Craiova, Romania \\ EUniversity of Medicine and Pharmacy of Craiova, Bucharest Universitary Emergency Hospital, Surgery Department, 2 Petru \\ Rares Str, 200349, Craiova, Romania \\ UUniversity of Medicine and Pharmacy of Craiova, Pharmacology Department, County Hospital of Craiova, 2-4 Petru Rares Str., \\ 200349, Craiova, Romania \\ ${ }^{7}$ Emergency Clinical Hospital of Craiova, Department of Diabetes, Nutrition and Metabolic Diseases, Tabaci Str, 200642, Craiova, \\ Romania \\ ${ }^{8}$ University of Medicine and Pharmacy of Craiova, Department of Metabolism and Nutrition Diseases, Filantropia Clinical \\ Hospital of Craiova, 1 Filantropiei Str., 200143, Craiova, Romania
}

\begin{abstract}
Metabolic syndrome (MS) is defined as a complex entity that involves the accumulation of cardiovascular and metabolic risk factors represented by: abdominal obesity, insulin resistance, hypertension, dyslipidemia [1]. The presence of MS correlates with the risk of cardiovascular disease in people without diabetes mellitus (DM), as well as those with type 2 DM [2-8].Visceral adipose tissue is an active metabolic organ and abdominal obesity is an independentrisk factor for metabolic disorder present in MS [9,10,11], associated with the development of cardiovascular disease and type 2 diabetes in children, adolescents and adults [1215]. Our findings have shown an association of visceral adiposity index (VAl) with MS in both men and women with prediabetes and diabetes, these findings allow us to conclude that VAl is a simple but effective indicator for estimating the presence of MS among adults.
\end{abstract}

Keywords: Metabolic syndrome, visceral adiposity index, diabetes, prediabetes, cardiovascular risk

MS is a multiplex risk factor that increases cardiovascular risk compared to the isolated existence of traditional risk factors and association with Type 2 DM determines an additional risk of CV events and mortality $[16,17]$.

The root of these problems is abdominal obesity, which in time becomes the bridge between vascular and metabolic risk, treated as a standalone clinical entity, namely cardio-metabolic risk [18,19].

It is useful to have a potential marker of cardiovascular and metabolic risk because the number of people with cardiovascular risk has reached alarming levels in the last years [20]. Thus, Amato et al., in a study of a European Caucasian population, validated a visceral obesity index defined as the Visceral Adiposity Index (VAl). VAl could become an easy-to-use tool in everyday practice that highlights cardiometabolic risk. The VAl formula considers gender (M/F), anthropometric measurements (abdominal circumference, body mass index), biochemical tests (triglycerides, HDL cholesterol).

\section{Experimental part}

\section{The aim of the study}

The aim of this study is to identify the utility of the visceral adiposity index (VAI) in predicting the presence of metabolic syndrome.

\section{Materials and method}

The study was conducted over 3 years (2011-2014) and included patients with diabetes mellitus, prediabetes and subjects without diabetes or prediabetes. The study, epidemiologically, transversally, non-interventionally, was conducted by analyzing 300 subjects divided into three subgroups, as follows: Subgroup 1 included 100 prediabetic patients; Subgroup 2 included 100 patients with type 2 diabetes and subgroup 3 (control) of 100 individuals randomly recruited without diabetes or prediabetes.

In these patients, the following anamnestic data were recorded: age, sex, personal history of diabetes and hypertension. Clinically, the following data were evaluated: weight, height, body mass index (BMI), waist circumference (WC), blood pressure (BP) measurement.

Venous blood was harvested from which the following tests were performed: blood glucose, $\mathrm{HbAlc}$ value, total cholesterol, HDL-cholesterol, LDL-cholesterol, triglycerides. Oral glucose tolerance test (OGTT) was performed in all patients included in the prediabetes subgroup, who had either glucose-lowering (IFG) or low glucose tolerance (IGT) and all patients without DM or prediabetes (132 patients at who had OGTT, a number of 100 had normal values, the rest of 32 had either prediabetes or diabetes). 
The diagnosis of metabolic syndrome was established according to the criteria proposed by IDF, NCEP ATP III, harmonized (2009), requiring at least 3 conditions: WC > $102 \mathrm{~cm}$ in men and $>88 \mathrm{~cm}$ in women, $\mathrm{TG} \geq 150 \mathrm{mg} / \mathrm{dL}$, $\mathrm{HDL}-\mathrm{c}<40 \mathrm{mg} / \mathrm{dL}$ in men and $<50 \mathrm{mg} / \mathrm{dL}$ in women, $\mathrm{BP} \geq 130 / \geq 85 \mathrm{mmHg}$, fasting glycemia $\geq 100 \mathrm{mg} / \mathrm{dL}$.

The calculation of visceral adiposity index (VAI), according to gender, has been achieved by the following formulas, where VAl = visceral adiposity index, $\mathrm{WC}=$ waist circumference, $\mathrm{BMI}=$ body mass index, $\mathrm{TG}=$ triglycerides, $\mathrm{HDL}=\mathrm{HDL}$ Cholesterol (fig. 1 and 2).

$$
\begin{aligned}
& \text { Males: VAI }=\left(\frac{\mathrm{WC}}{39.68+(1.88 \times \mathrm{BMI})}\right) \\
& \times\left(\frac{\mathrm{TG}}{1.03}\right) \times\left(\frac{1.31}{\mathrm{HDL}}\right) \\
& \text { Females: VAI }=\left(\frac{\mathrm{WC}}{36.58+(1.89 \times \mathrm{BMI})}\right) \\
& \times\left(\frac{\mathrm{TG}}{0.81}\right) \times\left(\frac{1.52}{\mathrm{HDL}}\right)
\end{aligned}
$$

Fig. 1. VAl formula for men

The data obtained was recorded as a Microsoft Excel spreadsheet and analyzed for each of the three groups using Microsoft Excel (Microsoft Corp., Redmond, WA, USA) together with XLSTAT 2014 for Microsoft Excel (Addinsoft SARL, Paris, France) and IBM SPSS Statistics 17.0 (IBM Corporation, Armonk, NY, USA) to analyze the relationships between clinical and paraclinical data of patients. For statistical analysis, the SPSS (Statistical Package for Social Sciences) version 17.0 for Windows was used.

\section{Results and discussions}

Each group comprised patients equally divided by age and gender. The decades of age in which the patients of each group were assigned are shown in table 1.

In women, there were statistically significant differences $(p<0.05)$ among the 3 sub-groups regarding to the presence of MS: in the control sublot MS was found in $24 \%$ of women, in the $36 \%$ in the prediabetes group and in $44 \%$ of diabetes subgroup (fig. 3 ).

Table 1

DECADES OF AGE AND SEX DISTRIBUTION OF THE THREE GROUPS

\begin{tabular}{|c|c|c|}
\hline Decades & No. MEN & No. WOMEN \\
\hline $20-39$ years & $1(2 \%)$ & $1(2 \%)$ \\
\hline $40-59$ years & $17(34 \%)$ & $17(34 \%)$ \\
\hline $60-79$ years & $32(64 \%)$ & $32(64 \%)$ \\
\hline TOTAL & $50(100 \%)$ & $50(100 \%)$ \\
\hline
\end{tabular}

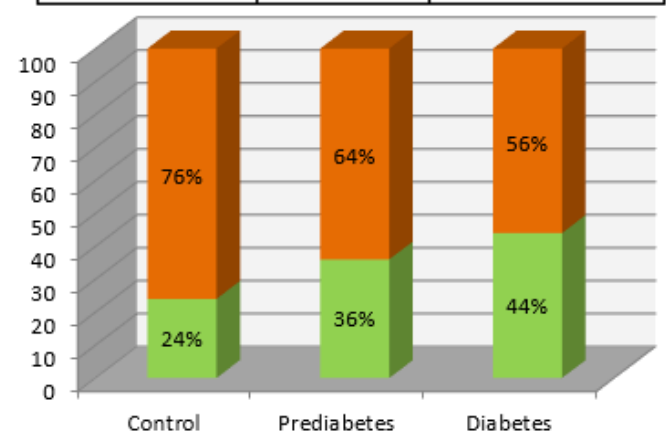

Fig. 3. Prevalence of metabolic syndrome in women in the subgroups
In men, in the control subgroup MS was found in $14 \%$ of men, in the prediabetes subgroup was $34 \%$, while in the diabetic group MS was presentin $38 \%$ of males, statistically significant difference $(p<0,05)$ (fig. 4).

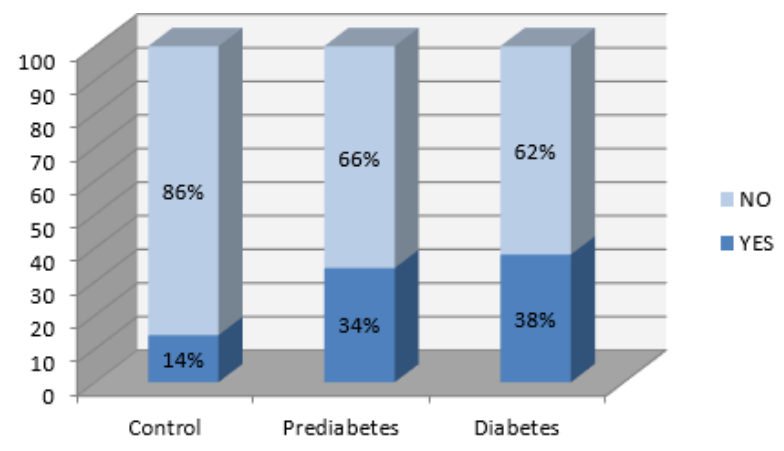

Fig. 4. Prevalence of metabolic syndrome in men in the 3 subgroups

Although women exhibited metabolic syndrome higher than men in all three subgroups, the differences were statistically insignificant $(p=0.701)$.

The prevalence of MS among the 300 patients analyzed was $32.3 \%$.

By comparing visceral adiposity index (VAl) we obtained an average of 4.99 for prediabetic patients, the higher value, respectively 6.22 for patients with DM and the smallest average value of 4.85 being found in the control sublot, statistically significant difference between subgroups ( $p$ $=0.039$ ) (table 2).

Regarding MS diagnosis, a positive linear correlation of the VAl value with the presence of MS was revealed in the control group, the median value of VAl in individuals with MS was 7.73 compared to the value of 2.78 registered in individuals without MS, statistically significant difference $(p<0.001)$.

In the prediabetic group, the VAI value was positively correlated with the presence of MS, MS patients with an average VAI of 6.57 greater than the 3.26 of non-MS patients, statistically significant difference $(p<0.001)$.

The same situation was also found in the diabetes group, the mean value in patients with MS with a value of 6.47, higher than the 1.69 value of non-MS patients, statistically significant difference $(p<0.001)$.

In this case, in all subgroups, the increased VAl has been shown to be predictable for MS (fig. 5).

The metabolic syndrome had a prevalence of $32.3 \%$ in this study, close to the $25 \%$ estimated by IDF worldwide.

The metabolic syndrome has a particular impact on the individual and population level through the increasing frequency of its presence and the cardiovascular risk it causes. The increase in MS prevalence among the population is closely linked to the worrying rise in the prevalence of obesity, which has become epidemic around the world.

In 1997, World Health Organization data showed that the prevalence of overweight and obesity increased by 10 -

Table 2

VAI EVALUATION IN THE 3 SUBGROUPS

\begin{tabular}{|l|c|c|c|c|}
\hline \multicolumn{1}{|c|}{ Variable } & GROUP & Mean (SD) & $95 \% \mathrm{CI}$ & P \\
\hline Visceral adiposity & SUBGROUP 1 & $4.99(4.04)$ & $4.182-5.805$ & 0.039 \\
index (VAI) & SUBGROUP 2 & $6.22(4.19)$ & $5.393-7,066$ & \\
& SUBGROUP 3 & $4.85(4.13)$ & $4.016-5.7$ & \\
& & & & \\
\hline
\end{tabular}




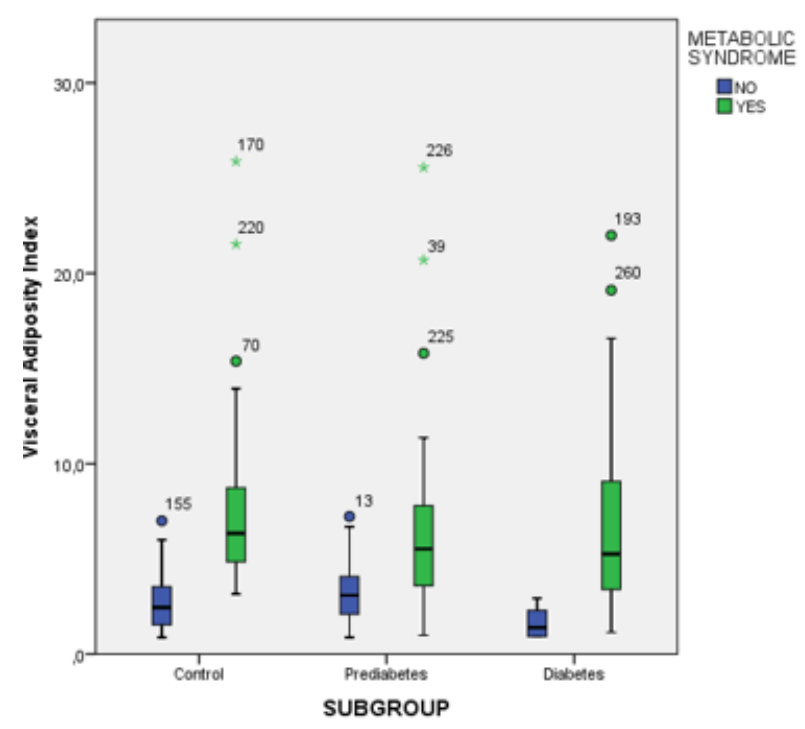

Fig. 5. Correlation of VAl with the diagnosis of metabolic syndrome in the 3 subgroups

$40 \%$ over the past ten years. An estimated 302.1 million adults with obesity ( $8.2 \%$ of the world's population) are estimated globally, with a higher percentage in developed countries $(20.4 \%)$ and in the developing countries (7.1\%).

In the developed countries, the high prevalence of obesity is generally correlated with low social, economic and educational status, while in the developing countries it is a result of lifestyle optimization, following urbanization and modernization. In the US, the proportion of overweight has increased by more than $30 \%$ since the 1980 s, reaching $61 \%$ of the population overweight and $26 \%$ of obesity. It is thus explicable that about 1 adult in $4(23 \%)$ has metabolic syndrome. It is thought that annual, overweight and obesity, are responsible for death in 300,000 cases, the costs associated with this pathology being $\$ 117$ billion / year. With age, the prevalence of metabolic syndrome increases to $50 \%$.

The current study shows a significant correlation of VAI values in both men and women with prediabetes and diabetes with MS.

\section{Conclusions}

Women showed higher metabolic syndrome than men in all 3 subgroups, but the differences were statistically insignificant ( $p=0.701$ ). MS prevalence among the 300 patients under study was $32.3 \%$

The diagnosis of MS was positively correlated with the VAl value in all 3 studied subgroups $(p<0.001)$, thus proving that an increased VAl value is predictable for MS.

Our results demonstrated an association of VAI with MS in both men and women with prediabetes and diabetes, these findings allow us to conclude that VAl is a simple, but effective indicator for estimating the presence of MS among adults.

\section{References}

1. *** AACE/ACE Consensus Statement, Endocrine Practice, 2018, 24:1. 2. ISOMAA B, ALMGREN P, TUOMI T, FORSEN B, LAHTI K, NISSEN M, TASKINEN M-R, GROOP L, Diabetes Care, 2001, 24, p. 683-9.

3. LAKKA H-M, LAAKSONEN DE, LAKKA TA, NISKANEN LK, KUMPUSALO

E, TUOMILEHTO J, SALONEN JT, J ama, 2002, 288, p. 2709-16.

4. RADU L, VLADU M.I., MIHAI M.G., CLENCIU D., DIJ MARESCU A.L., ENE C.G., TENEA-COJAN T.S., Research and Science Today Journal (Tg. Jiu), Suppl. August 2018, p. 32-40.

5. CLENCIU D., VLADU M.I., TENEA-COJAN T.S., RADU L., Research and Science Today Journal, (Tg. Jiu), Suppl. August 2018, p. 6-23.

6. SATTAR N, GAW A, SCHERBAKOVA O, FORD I, O'REILLY DS), HAFFNER SM, ISLES C, MACFARLANE PW, PACKARD CJ, COBBE SM, SHEPHERD J., Circulation, 2003, 108, p. 414-9.

7. DEKKER J M, GIRMAN C, RHODES T, NIJ PELS G, STEHOUWER CDA, BOUTER LM, HEINE RJ., Circulation, 2005, 112, p. 666-73.

8. SAELY CH, ACZEL S, MARTE T, LANGER P, HOEFLE G, DREXEL H., J Clin Endocrinol Metab, 2005, 90, p. 5698-703.

9. AMATO MC, GIORDANO C, GALIA M, CRISCIMANNA A, VITABILE S, MIDIRI M ET AL., Diabetes Care, 2010, 33(4), p. 920-2.

10. STREBA LAM, CARSTEA D, MITRUT P, VERE CC, DRAGOMIR N, STREBA CT., Rom J Morphol Embryol, 2008, 49:1, p. 13-20.

11. AMATO MC, GIORDANO C, PITRONE M, GALLUZZO A., Lipids Health Dis, 2011, 10:183, p. 1-8.

12. VLADU, I.M, RADU, L., GIRGAVU, S.R., TENEA COJAN, T.S., ENE, C.G., CALBOREAN, V., GHEORMAN, V., CLENCIU, D., Rev. Chim. (Bucharest), 69, no. 9, 2018, p. 2479-81.

13 LAKKA HM, LAAKSONEN DE, LAKKA TA, NISKANEN LK, KUMPUSALO E, TUOMILEHTO J, ET AL., J ama, 2002, 228:21, p. 270916.

14. ENE, C.G., ROSU, A., GHEORMAN, V., CALBOREAN, V., TENEA COJAN, T.S., ROGOVEANU, O. C., VLADU, M. I., RADU, L., Rev. Chim. (Bucharest), 69, no. 7, 2018, p. 1851-4.

15.CODONER-FRANCH P., MURRIA-ESTAL R., TORTAJ ADA-GIRBES M., CASTILLO-VILLAESCUSAC., DEL VALLS-BELLESV., ALONSO-IGLESIAS E., Nutr Hosp, 2010, 25:5, p. 845-51.

16. PITANGUEIRA J.C.D., SILVA L.R., SANTANA M.L.P., SILVA M.C.M., COSTA P.R.F., D'ALMEIDA V., ET AL., Nutr Hosp, 2014, 29, p. 865-72.

17. FORTOFOIU M., FORTOFOIU M.C., COMANESCU V., DOBRINESCU A.C., PADUREANU V., VERE C.C., STREBA C.T., CIUREA P.L., Rom J Morphol Embryol, 2015, 56:4, p. 1461-5.

18. BALOSEANU C.L., STREBA C.T., VERE C.C., COMANESCU V., ROGOVEANU I., Rom J Morphol Embryol, 2012, 53:3, p. 609-14.

19.VREJU F.A., CIUREA M.E., POPA D., POPA F., PARVANESCU C.D., CHISALAU B.A., BARBULESCU A.L., PARVANESCU V., ROSU A., CIUREA P.L., Med Ultrason, 2016, 18:1, p. 90-5.

20.STREBA C., VERE C.C., NEAGOE D., STREBA C.T., PREJ BEANU I., IANOSI G., COMANESCU V., PIRICI D.N., Rom J Morphol Embryol, 2010, 51:3, p. 509-14.

Manuscript received: 18.05 .2018 